\title{
PROBLEMATIKA MENULIS BAHASA ARAB
}

\author{
Neli Putri \\ Dosen Fakultas Tarbiyah IAIN Imam Bonjol Padang \\ e-mail: putri_neli@ymail.com
}

\begin{abstract}
Writing is one of language skills that should be acquired by Arabic students. It may be difficult for students to learn Arabic because it is one foreign languages. Many students get difficulties in writing in Arabic language because they should pay attention to imlaiyah structure in writing words to sentences. It is very danger If the students write a verse of Alquran and hadist incorrectly. Indeed, the understanding of structure of Arabic in writing should be taken in to account as importance skill by Arabic and Islamic education students.
\end{abstract}

\begin{abstract}
Abstrak: Menulis merupakan salah satu bentuk keterampilan yang diharapkan dari pembelajaran bahasa Arab. Bahasa Arab sebagai bahasa asing, maka tidak mustahil bagi seseorang akan menemui kesulitan dalam mempelajarinya dan kesalahan dalam menulisnya. Penulisan bahasa Arab harus memperhatikan kaidah imlaiyah mulia dari penulisan kata hingga kalimat. Penulisan kata yang salah akan berpengaruh kepada perubahan makna. Apabila kalimat yang ditulis berupa ayat atau hadis, maka akan sangat berakibat fatal bahkan bisa menyesatkan. Jadi pengetahuan tentang kaidah-kaidah menulis bahasa Arab harus dipahami dan dikuasai dengan baik oleh pendidik agama Islam dan bahasa Arab.
\end{abstract}

Kata Kunci: Menulis, Kesulitan, Kaidah-kaidah Bahasa Arab

\section{PENDAHULUAN}

Untuk memperoleh penulisan Arab yang benar bahkan bagus diperlukan pengetahuan tentang kaidah menulis Arab (qawaidul imla' al- Arabiy wal khath al- "Arabiy). Kaidah imlak merupakan ketentuan penulisan kata-kata dan kalimat Arab yang tingkat kebenarannya dapat dilihat diantaranya dari aspek nahu dan sharaf, ilmu ashwat terkait dengan makharijul huruf, dan kaidah penulisan huruf-huruf sendiri. Adapun kaidah khath merupakan aturan penulisan huruf, kata, dan kalimat dengan indah sesuai dengan jenis khath yang dimaksud. Kaidah khath menjadi penyempurna bagi kaidah imlak, karena tulisan yang indah akan memberikan nilai tambah bagi seorang pembaca, seperti mudah dibaca, menarik karena indah dipandang mata.

Tulisan ini difokuskan pada penjelasan terkait kaidah imlak, karena tanpa memahami aturannya maka akan berdampak pada makna kata dan kalimat yang dimaksudkan, apalagi jika dalam ayat al-Quran dan hadis Nabi SAW.

\section{PEMBAHASAN}

Keterampilan menulis dalam bahasa Arab mencakup tiga bentuk yaitu menulis bentuk huruf, kata dengan tulisan yang indah, menulis imlak, dan menulis tingkat atas yaitu mengarang. Adapun yang dimaksud dengan menulis bahasa Arab dalam tulisan ini adalah menulis dengan makna imlak dan imlak ada dengan cara mencontoh, menyalin, dan dikte.

Kebutuhan dan tuntutan menulis Arab dengan benar adalah sebuah kemestian. Banyak kesulitan dan kesalahan yang dialami seseorang dalam menulis karena tidak paham dengan aturan menulis. Kesulitan dan kesalahan muncul tidak dalam bentuk menyalin atau mencontoh sebuah tulisan Arab saja, akan tetapi ketika dibacakan dan didengarkan (dikte).

Pada satu sisi ada kesamaan kaidah dasar untuk menulis Arab dengan bahasa Indonesia misalnya. Kesamaan itu diantaranya menulis kata sesuai dengan apa yang diucapkan atau didengar. Mushtahafa Ghalayaini mengatakan bahwa asal penulisan setiap kata adalah ditulis sebagaimana bentuk pengucapannya di awal atau diakhir (Ghalayaini, 1987: 137). Namun di dalam penulisan bahasa Arab ada beberapa kaidah dasar lainnya yang harus diketahui si penulis. 
Kaidah-kaidahnya adalah:

1. Menulis kata sesuai dengan bacaannya (yuktabu ma yunthaq). Maksudnya jika sebuah kata hurufnya diucapkan tidak panjang (mad dengan alif, waw dan ya') maka harus ditulis tidak panjang atau sebaliknya jika dibaca panjang maka harus ditulis panjang.

2. Tidak menulis kata yang hanya ada dalam pengucapan, artinya kata-kata yang dibaca mad dan tanwin tidak dituliskan alif madnya atau nun pada akhir kata yang bertanwin, seperti kata tuhan (إلـــ):di baca :ilaahun, huruf lam harus dibaca panjang tetapi tidak ditulis alif mad sesudah lam:إ dan ha' dibaca hun dengan tanda tanwin bukan ditulis dengan menambahkan nun diakhir ha' إلإن:

3. Menulis kata yang unsurnya harus ditulis tetapi tidak dibaca, seperti kata: اولئك, اولو, , huruf waw yang terletak sesudah hamzah tidak dibaca dan bukan sebagai mad akan tetapi harus ditulis. (Ghalayaini: 1987: 137-40)

Kekeliruan sering terjadi pada kaidah kedua dan ketiga. Kaidahnya sangat berkaitan dengan pengetahuan bahasa Arab, seperti penguasaan kosa kata dengan tulisannya, nahu, sharaf, ilmu ashwat. Akan tetapi kesalahan ini tidak bertumpu pada aspek kaidah saja akan tetapi ada faktor lain yang mempengaruhi.

Di antara kaidahnya berkaitan dengan penambahan (ziyadah) huruf dan penghapusan huruf (hazaf), karena adakalanya penulisan kata Arab apabila sudah dirangkai menjadi sebuah kalimat akan ditemukan kata-kata yang hanya ada dalam pengucapan tetapi tidak ada dalam tulisan atau sebaliknya hanya ada dalam tulisan tetapi tidak ada dalam pengucapan. Bahkan ada yang berbeda pengucapan huruf dengan yang huruf tertulis. Seperti kata كتابُ kata ini dibaca kitaabun maka dalam penulisan bisa jadi akan ditulis menjadi كتابن, penulisan kata-kata

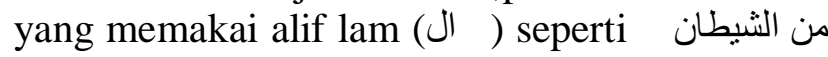
dibaca dengan tidak membaca alif lamnya, maka bisa jadi ditulis dengan membuang alif lamnya karena tidak ada dalam bacaan : منشيطان.
Lebih lanjut di bawah ini akan dijelaskan kaidah-kaidah imlak secara rinci (Yamin: 1982:235-240)

1. Ziyadah atau penambahan alif dan waw (yang ada hanya dalam tulisan tidak dalam bacaan) --penambahan alif terdapat pada akhir kata-kata:

a. keadaannya manshub dalam bahasa Arab, sepertic: ان محمدا kata Muhammad mendapat tambahan huruf alif di belakang dal dan huruf alif itu adalah alif tanwin nasab karena kata Muhammad manshub dengan masuknya huruf anna

b. sesudah waw jamak, seperti pada عملوا: kata

c. pada kata مائة

--penambahan waw, terdapat pada kata:

a) أولئك ,أو لاء, أولي, أولات, أولو

b) عرو jika dalam keadaan marfu' dan majrur

2. Hazfu atau penghapusan (dibuang) alif, waw, dan ya', terdapat pada kata:

-- hazaf alif , terdapat pada kata-kata sebagai berikut:

a) ذلك,هذه ,هذا: الإشارة اسمان ,

b) apabila dimasuki oleh salah satu hhuruf jar seperti: ماب عن ألأ الاج؟,عم؟ =

c) fi'il mudhari'majzum mu'tal akhir

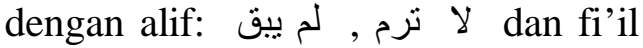
amarnya: ارم,ارض له

d) pada kata-kata: الرحمن ,طه ,لكن ,اله, الهم, أولئك

Selain kata-kata di atas terdapat katakata yang boleh dibuang alifnya dan ada yang boleh tulis, seperti pada huruf ha' tanbiih: هأناذا ,هأنتم, dan ya' huruf nida': يـايهالذى , هالنى, pada nama orang seperti: ابر هيم, اسحق ,اسمعيل, ثلثمائة ,السموات ,سليمن ,هرون

--hazaf waw, terdapat pada kata-kata:

a) عمرو jika dalam keadaan nashab, إن عمرا طالب :seperti dalam kalimat

b) pada akhir fi'il amar dan mudhari' mu'tal akhir yang asal alifnya waw, seperti: امح اللوح_لم, يبيد جميلا

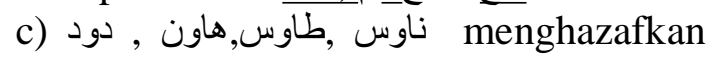
waw kata-kata ini bersifat jawaz artinya boleh dibuang boleh tidak 
--hazaf ya' terjadi pada :

a) akhir isim manqus yang tidak mudhaf atau di awali dengan "alif lam" dalam keadaan marfu' dan majrur, seperti: بو اد مررت بـ قام قاض

b) akhir fi'il mudhari' majzum dan amar mu'tal ya'iy, seperti: اكو , لا تبغ الفساد ثيابك

c) kata-kata أبني ,عمي ,أبي , أمي ,ربي jika

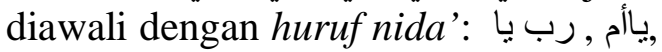
يابن , عزّ يا ,أب يا

3. Penulisan Hamzah ( $\sigma^{*}$ ).

Hamzah dalam sebuah kata ada yang di awal letaknya, ada yang di tengah, dan di akhir. Hamzah adalah huruf yang tidak ada bentuk tetapi dia diberi tempat, rumah atau kursi, seperti kursi alif (أ), kursi waw (و), dan kursi ya' (s), adakalnya juga ditulis berdiri sendiri ( $₫$ ). Contoh dalam kata:

- letaknya di awal kata: أساس ,إلى , أولنئك, أخذ, أمن

- أرأرة, لؤم ,صائم ,سأل : letaknya di tengah kata سئل ,شؤم ,بيئة ,تفاؤل ,رعوف ,ساءل ,بئس

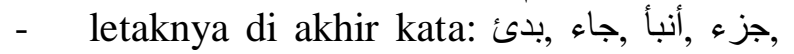

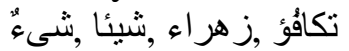

Berdasarkan contoh-contah penulisan hamzah pada kata-kata di atas diketahui bahwa dengan berbedanya posisi hamzah dalam sebuah kata, maka rumah hamzah juga beragam. Perbedaan rumah hamzah adakalanya berdasarkan harkat hamzah itu sendiri dan adakalanya berdasarkan harkat huruf yang sebelumnya.

4. Penulisan Alif lam (Qamariah dan Syamsiah)

Sebuah kata apabila diawali dengan alif lam maka cara membacanya ada dua macam, yang pertama lam yang ada pada alif lam (المدرسة akan terbaca, seperti ) inilah yang dimaksudkan dengan alif lam qamariah dengan ketentuan jika kata-kata arabnya diawali salah satu huruf qamariah. Huruf-huruf yang dimaksudkan adalah: ', ب, ي ,هـ ,و, ,م, ,ق , ف, ,

Kedua lam yang ada pada alif lam tidak terbaca akan tetapi lebur dengan huruf yang sesudahnya, seperti kata: الستّلام, di baca "assalaam" yang ditandai dengan adanya tasydid (syiddah) di atas huruf sin. Inilah yang disebut dengan alif lam syamsiah dan ketentuan bacaan seperti demikan dengan ketentuan jika kata-kata arabnya diawali dengan salah satu huruf syamsiah. Hurufhuruf yang dimaksudkan adalah: $ت, \dot{\lrcorner},\lrcorner, \dot{\lrcorner}$,$\lrcorner ,$ ن ,ل, , ط, ص ,ص ش , ,

5. Penulisan Alif Tanwin Nashab

Maksudnya adalah jika sebuah kata pada akhirnya dibaca dengan bunyi bertanwin dalam keadaan nashab dengan fathah (ditandai dengan bunyi "an") maka dalam penulisannya adakalanya dengan menambahkan alif di akhir kata tersebut, seperti kata "qalaman" dalam kalimat (jumlah arabiyah) berikut:إنتريت فلـما dan adakalanya tidak ditambahkan seperti kata " thalibatan” pada kalimat: طالبـة عفيفة كانت

6. Penulisan $t a$ ' pada akhir kata

Ta' pada akhir sebuah kata mempunyai dua macam / bentuk yaitu:

a) Ta' Marbutah ( $\ddot{a}$ )

Ta' ini biasanya untuk menunjukkan kata perempuan (mu'annas), seperti عزيزة, tetapi ada juga untuk memnunjukkan banyak (jamak), seperti: قضاة bentuk plural dari kata قاض , atau untuk menyatakan bersangatan (mubalaghah), seperti: فهّامـة

Huruf Ta ini apabila dibaca wasal dengan kata yang sesudahnya tidak berubah, tetapi apabila berhenti maka akan dibaca dengan huruf ha, seperti kalimat di bawah ini: طالبَة رأيت dan إن قضاة مكة _عادلون

Kata " طالبَة "ta' marbutah di akhirnya dibaca dengan hutuf ha' karena wakaf, jika tidak wakaf huruf ta' tetap dibaca sebagaimana bunyinya yang sesuai dengan i'rab katanya dalam kalimat yaitu yaitu mansub maka ta' fathah bertanwin (thalibatan).

Ketentuan penulisan ta' ini adalah jika terdapat pada kata-kata, sbb:

1- kata-kata terdiri dari lebih tiga huruf tidak sukun ditengahnya dan dia kata tunggal menunjukkan perempuan (isim muannas mufrad), seperti: شجرة, طفلة ,طاولة ,طبيبة

2- akhir nama orang (isim 'alam) yang berasal dari bahasa Arab (ghairu ajnabi), seperti: حمزة ,طلحة, , حعاوية, عتيبة ,عنترة 
3- akhir jamak taksir (yaitu bentuk kata yang menyatakan banyak tetapi tidak beraturan), seperti : أغضاة ,سعاة , , دعاة ,إخوة

4- akhir shighat mubalaghah, seperti: فهّامة ,فكارة, علامة

b) Ta Mabsuuthah/Thawilah/Mamdudah (ت)

Ta' ini jika berhenti dalam mengucapkannya maka bunyinya adalah " $t$ ". Huruf ta' adakalanya menjadi bagian pembentuk kata yang sifatnya asli, seperti kata: اصوات,صوت موت اتصوت dan ada yang menjadi tambahan, seperti kata: جتمعات ,مسلمات Huruf ta' ditulis mabsuuth (terhamapar) biasanya digunakan untuk menunjukkan kata perempuan (mu'annas) yang dinamakan dengan $\mathrm{Ta}^{\prime}$ ta'nis Sakinah pada fi'il madhi, seperti kata: . Lebih lanjut letak-letaknya terdapat pada:

1. akhir kata fi'il, isim (yang merupkan صuruf asli), seperti: صنت, هكت هيهات, هات, بيت

2. kata-kata yang berbentuk jamak (plural) untuk perempuan yang sebelumnya terdapat alif tambahan, seperti: طالبات مدرسات, طاو لات

\section{i. 3. kata ganti (dhamir), seperti:}

3. akhir nama-nama asing (ajnabiy), seperti: هاروت, ماروت, بونابرت, زر ادشت

4. akhir kata bentuk banyak tidak beraturan (jamak taksir) yang bentuk tunggalnya diakhiri dengan ta' mabsuuthah, seperti: أوقات :وقت, ابيات,بيوت:بيت,نباتات:نبات

5. kata-kata yang diakhiri dengan ta' dan sebelumnya huruf ya' dan waw sukun, seperti : عنكبوت, بيروت, كبريت, عفريت

Selain ketentuan di atas terdapat penulisan ta' yang diluarnya, seperti ditemukan dalam al-Quran kata-kata yang seharusnya diakhirnya ditulis dengan ta' marbuuthah tetapi ditulis dengan ta' mabsuuth, seperti : إمرأة jika disandarkan kepada nama suami maka ta' ditulis dalam bentuk mabsuuthah, seperti kata-kata: . Selain kata-kata di atas juga ada kata-kata lain yang ditulis ta' marbuthnya dengan ta' mabsuutah dengan ketentuan jika disandarkan kepada kata
Allah atau rabb, seprti kata: رحمة, نعمة, لعنة, مرضاة

Selanjutnya keberhasilan seseorang dalam menulis banyak dipengaruhi oleh factor, baik faktor intern maupun ekstern. Terampil atau pandai menulis tidak terlepas dari proses belajar mengajar. Apabila pembelajarannya dapat diikuti dengan baik maka hasilnya akan baik, sebaliknya jika pembelajarannya kurang baik maka hasil kurang baik juga. Namun dalam PBM dapat dipahami bahwa adanya hasil yang beragam adalah suatu yang wajar karena tidak semua anak mempunyai kemampuan sama, seperti halnya dalam menulis Arab ini. Apabila anak didik sudah mempunyai pengetahuan dasar dan sudah dapat pengalaman belajar menulis maka kesalahan yang dilakukan tidak akan banyak seperti yang dialami oleh anak yang belum pernah/ punya pengalaman sama sekali. Penyebab kesalahan dalam menulis Arab ini khususnya dipengaruhi oleh banyak factor.

Diantara sebab-sebab kesalahan menulis (imlaiyyah) dilihat dari beberapa faktor (Khathir dkk,1989:294)

1. Faktor yang berkaitan dengan bahasa Arab sendiri.

Bahasa Arab merupakan bahasa yang paling unik dan bahasa yang paling kaya dibanding dengan bahasa-bahasa yang ada di dunia. Mulai dari huruf-hurufnya, bentuk hurufnya, perobahan-perobahan bentuk kata dari satu kata menjadi beberapa kata baru lain yang mempunyai makna tersendiri pula, sehingga dikatakan bahwa bahasa Arab mempunyai ciri-ciri dan kharakter tersendiri, diantaranya seperti:

a. Ada huruf-huruf yang sama bentuk dan dibedakan bunyinya dengan berbedanya titik contohnya huruf :" $b a, \quad t a$, tsa",,"ja,ha, kha”, “dal, dzal", "ra, zal", "sin, syin", shad, dhadh”, tha, dha", ain, ghain"

$b$. Ada huruf-huruf yang berdekatan tempat keluarnya dalam pengucapan (makhrajnya) dan berbeda bentuknya contoh antara bunyi dzal, zal,tsa, sin, syin,shad, ha kecil, ha besar, qaf, kaf

c. Ada perbedaan penulisan karena berbedanya suara yang dibunyikan antara panjang dan pendek, adanya 
istilah fashal dan washal yaitu kapan penulisan sebuah kata boleh di sambung atau dipisah dengan kata -kata lain.

d. Ada undang-undang penulisannya (kaidah imlak)

e. Adanya perbedaan ejaan yang biasa digunakan dengan ejaan yang terdapat di mushhaf, seperti ditemukannya istilah ziyadah dan hazaf (penambahan dan pengurangan huruf) pada penulisan.

f. Ada kaidah khusus terkait nahu dan sharaf.

Mengenali bahasa yang akan ditulis adalah sangat penting karena dari tulisan yang kita tulis diharapkan orang lain bisa membacanya dan mengerti.

2. Faktor yang berkaitan dengan kemampuan personilnya, seperti anak ragu dan tidak dapat membedakan bunyi atau suara huruf yang berdekatan makhrajnya, dan lemahnya alat indra (termasuk mata, tangan untuk menulis, mulut sebagai alat ucap dan berbicara). Di sisi lain juga karena anak tidak dapat mengingat atau menangkap apa yang sudah diajarkan dengan baik karena rendah/lemahnya tingkat kecerdasan. Di samping itu, jarang latihan menulis tersebut baik di sekolah atau di rumah. Latihan yang kontiniu itu sangat penting karena merupakan usaha perbaikan dan peningkatan mutu dan kualitas hasil kerja atau sebuah keterampilan.

3. Faktor guru yang kurang menguasai teknik-teknik penulisan aksara Arab, dan kurang memberikan perhatian kepada siswa, serta tidak melakukan upaya perbaikan terhadap kesalahan-kesalahan yang ditemukan pada tulisan anak. Guru adalah faktor yang sangat menentukan berjalannya dan terjadinya proses belajar yang baik sehingga memperoleh hasil yang baik juga. Di samping itu, guru juga harus menguasai materi apa yang akan diajarkan, jika berupa keterampilan maka otomatis dia harus menguasai teori dan prakteknya atau juga harus terampil lebih dahulu, sehingga dapat terhindar dari kesalahan-kesalahan dalam menerapkannya pada anak didik.
4. Faktor metode pembelajarannya. Metode merupakan faktor yang cukup menentukan untuk mendapatkan hasil yang baik karena apabila cara atau metode belajarnya tidak baik dan tidak jelas maka hasil yang diharapkan tidak akan terwujud. Apabila yang diharapkan anak terampil dalam menulis maka guru harus memilih metode yang cocok untuk pembelajarannya, dan tidak mungkin memilih metode belajar yang tidak ada unsur praktek/penerapan dan demontrasinya dari guru yang mengajar, serta latihan yang memadai. Jika tidak memperhatikan hal ini maka tujuan belajar tidak akan tercapai, sekalipun guru yang mengajar menguasai teori secara sempurna dan menyampaikan kepada siswanya. Mahmud Yunus mengatakan bahwa "metode lebih penting dari pada materi", artinya metode yang digunakan oleh guru menjadi kunci untuk pencapaian hasil belajar.

Senada dengan penjelasan di atas bahwa untuk mendapatkan hasil tulisan Arab yang benar dan baik terhindar dari kesalahan si penulis harus mengetahui dan menguasai tata cara penulisannya serta kaidah bahasa yang terkait dengannya seperti kaidah imlak sendiri dan kaidah bahasa Arab (nahu dan sharaf). Kesalahan dalam menulis dapat menyebabkan rusaknya makna yang dimaksud atau orang tidak mengerti apa maksud yang ditulis.

Ahli bahasa mengemukakan bahwa di antara kesalahan-kesalahan yang terjadi dalam menulis yang penting diperhatikan adalah:

1. Membedakan antara bunyi suara huruf yang mirip atau berdekat, seperti antara:

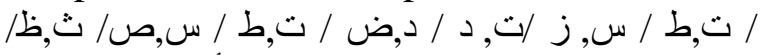

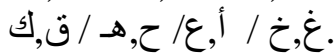

Apabila sebuah kata menggunakan salah satu diantara huruf yang hampir sama bunyi suaranya maka boleh jadi akan ditulis bukan huruf yang dimaksudkan, seperti kata: اهدنالصــراط المسـتقبم jika si penulis salah إحد نالسراط المصطقيم dengar maka akan ditulis Jadi pendengaran yang baik sangat membantu dalam menulis jika dibacakan atau disebutkan oleh orang lain.

2. Penulisan hamzah washal dan hamzah qatha', jika si penulis tidak mengetahui perbedaan pemakaian kata-kata yang 
menggunakan hamzah qataha' maka bisa jadi akan menulisnya dengan hamzah washal atau sebaliknya.

3. Kelalain penulis dalam memberi tanda hamzah pada kata yang diawali dengan hamzah qatha', padahal satu sisi menulis hamzah tersebut penting untuk membedakan dengan kata yang diwali dengan hamzah washal.

4. Penulisan hamzah yang berada pada tengah kata atau akhir kata. Karena dalam kaidah imlak penulisan hamzah yang berada pada posisi tersebut berbeda bentuk atau سأل, رعوس, جاء, شىء, rumahnya, seperti kata نشأ

5. Penulisan alif mamdudah dan alif maqsurah pada akhir kata. Seperti kata الفتى tidak boleh ditulis dengan alif mamdudah : الفتا

6. Menghazafkan (menghilangkan) huruf lam pada alif lam sebelum huruf syamsiah. Ini disebabkan bunyi lam lebur apabila sesudahnya diiringi oleh salah satu huruf syamsiah, seperti kata; الثنمس akan ditulis ini disebabkan karena bunyi huruf lam pada alif lam syamsiah tidak ada diucapkan ketika dibaca.

7. Tidak membuang huruf hamzah pada kata ابن yang seharusnya dibuang, seperti kata pada kata معاوية بن أبى سفيان

8. Penulisan ta' marbuthah dan ta' mabsuthah pada akhir kata, seperti kata جامعـة akan جامعت

9. Tidak membuang alif pada kata-kata yang seharusnya dibuang. Hal ini terjadi karena kata-kata tersebut dibaca panjang hanya dalam pengucapan tidak dalam tulisan, seperti kata-kata: الله, إله, لكنّ, لكن, هذا, هذه, ذللك, طه

10. Tidak membuang huruf alif lam pada sebuah kata yang dimasuki atau didahului oleh lam ibtida', seperti: 'لَّ + اللهُ maka penulisannya menjadi : للهو

11. Penulisan kata yang dibaca dengan idgham, seperti : من مـارزقتاهم kata yang bergaris dibaca dengan meleburkan bunyi nun kepada mim, maka yang terdengar adalah huruf mim bertasydid.

12. Memisahkan penulisan kata yang harusnya bersambungan, seperti kata; أمّا, لَّّا
13. Tidak menuliskan huruf pada sebuah kata sedangkan dia harus ditulis sekalipun tidak ada diucapkan, seperti penambahan waw pada kata عمرو : عan an alif pada kata

14. Menulis huruf nun di belakang kata yang bertanwin, karena dalam membacanya yang muncul diakahir adalah bunyi nun mati, عالمن عالمُ ditulis dengan عالم

15. Tidak menambahkan alif pada yang nasab dengan fathah, seperti kalimat: إنّ محمدا ذكيُ kata muhammad dibaca "muhammadan" dengan ketentuan diakahirnya harus ditambahkan alif (disebut juga alif tanwin nasab), jadi tidak ditulis seperti: محمد .

16. Menambahkan alif pada akhir kata kata yang nasab yang seharusnya tidak ditambahkan alif tanwin dibelakangnya, seperti معثمتأ sesdak ditulis

17. Memisahkan kata-kata yang wajib bersambungan, seperti: طالمـا, قلمـا, كلما, حيثما, (137) (Khuliy,1982:135-37)

Demikianlah penjelasan tentang kesalahan-kesalahan yang banyak terlihat dalam menulis Arab. Penulis melihat bahwa sumber kesalahan tersebut didominasi karena kurangnya pengetahuan si penulis tentang kaidah atau aturan menulis aksara Arab secara rasam imla'iy.

Akan tetapi di sisi lain pengetahuan terkait kata mufradat Arab, nahu dan sharaf juga sangat penting. Karena kecenderungan yang terlihat dalam menulis Arab si penulis sering mengabaikan keterkaitannya dengan cabang ilmu bahasa Arab lainnya, sehingga berakibat pada kesalahan. Ini berarti bahwa dengan dibekalinya seseorang dengan pengetahuan yang komprehensif tentang tata cara menulis Arab dan kaidah bahasa Arab itu sendiri kesalahan dalam menulis dapat diminimalisir. Dengan demikian inilah diantara faktor yang sangat menentukan bisa atau tidaknya seseorang dalam menulis Arab, di samping ada faktor metode, guru, dan lainnya yang ikut mempengaruhi berhasil atau tidaknya menulis Arab.

Kegiatan penting lain yang harus dilakukan jika ingin mendapatkan sebuah keterampilan menulis adalah latihan secara terus menerus sekalipun dalam waktu yang singkat. Tanpa latihan atau hanya dengan satu kali 
latihan menulis maka belum dapat menghasilkan tulisan yang benar, baik, dan memuaskan. Latihan yang continiu merupakan pembiasaan sehingga tidak akan merasa sulit bahkan mudah.

\section{DAFTAR RUJUKAN}

Khuliy, Muhammad Ali, 1982. Asalib Tadris alLughah al-'Arabiyah, Riyadh: Mamlakah as-Su'udiyah

\section{SIMPULAN}

Begitu pentingnya seorang penulis memahami kaidah-kaidah menulis Arab. Penulisan bahasa Arab mempunyai karakter dan ciri khas yang tidak dimiliki oleh bahasa dunia lain. Adanya fenomena kesalahan menulis Arab baik yang dihadapi oleh anak didik maupun pendidik dapat diatasi dengan memahami ketentuan yang ada, serta tidak mengabaikan latihan menulis yang kontiniu dan teruji.

Ghalayaini, Mushthafa, 1987. Jami' ad-Durus al-'Arabiy, Beirut: al-Maktabah al"ashriyah

Harun, Abdussalam Muhamad. Qawaidul Imla',th,ttp

Rusydi Khathir dkk, Mahmud: 1989. Thuruq Tadris al-Lughah al-Arabiyah wa alTarbiyah al-Diniyah", ttp

Ya'kub, Amil Badi', 1986. Mu'jam at-Thulab fil I'rab wal Imla', Beitut: Dar 'Ilmi

Yamin, Nashif, 1992. Al-Mu'jam al-Mufashshal fil Imla':qawa'id wa nushush, Beirut: Darul Kutub al-'ilmiyah 